\title{
Breeding behaviour of pilot whales revealed by DNA fingerprinting
}

\author{
BILL AMOS, JOHN BARRETT \& GABRIEL A. DOVER \\ Department of Genetics University of Cambridge Cambridge CB2 3EH, U.K.
}

\begin{abstract}
Most species of whale spend the majority of their lives well away from land, are capable of migrating over large distances and are difficult to identify individually. However, conservation measures require a detailed understanding of their social structure, breeding behaviour and migration patterns. The advent of DNA fingerprinting permits a systematic investigation of such parameters. In the Faeroe Islands there exists a traditional harvest of long-finned pilot whales (Globicephala melas), in which intact social groups (pods) are captured. This affords a unique opportunity to study genetic relationships within and between pods. We report here on a paternity analysis, using DNA fingerprinting, of mother-fetus pairs and males sampled from complete pods. In addition, a single, highly polymorphic minisatellite locus was used to infer degrees of relatedness between groups of fetuses and females. Taken together, our results suggest that pods consist of closely related adult females and their offspring. Sexually mature males either move frequently between pods or remain in their natal pod but refrain from mating with female relatives. Whichever hypothesis is correct, the data suggest that each male spends only a few months with the female post-mating and individual males often father several fetuses within a pod.
\end{abstract}

Keywords: DNA fingerprinting, minisatellite locus, pilot whales, social groups.

\section{Introduction}

The long-finned pilot whale Globicephala melas is a medium-sized whale, relatively abundant in the North Atlantic. Individuals swim in large groups, or pods, usually containing 50-200 animals but sometimes numbering thousands (Niclassen, 1945; a Ryggi 1935). Such pods appear to be very cohesive, to the point where they may be herded easily by a small number of boats. Over the centuries man has exploited this characteristic to obtain food, the whales being driven into shallow bays for slaughter. Today, only the Faeroe Islands continue to operate a traditional drive fishery. Although Sergeant (1962) has made a detailed study of many aspects of pilot whale biology through the analysis of whale pods taken in the Newfoundland fishery, additional information about the animal's behaviour can be gained from anecdotal observations made by Faeroese fishermen. An account of the history and mechanics of the Faeroese whale hunt, or 'grind' is found in Joensen (1976).

Pilot whale pods usually comprise individuals representative of all age/sex classes, although there is a pronounced bias towards females at maturity. Sergeant (1962) suggests that this is due to a lower male longevity. The female reproductive cycle is estimated to be about 3 years, of which gestation contributes about 15.5 months. Mating appears to be seasonal, with a peak in early summer, leading to a peak of births in late summer (Sergeant, 1962; A. Martin, personal communication). At any time, about 10 per cent of females were found to be pregnant. At present nothing is known about the relationships between individuals within a pod but there are several pieces of evidence to suggest at least some relatedness. Sergeant (1962) reports the presence of post-reproductive females in $G$. melas, and Kasuya \& Marsh (1984) report both postreproductive females and possible extended suckling by older females in the closely related G. macrorhynchus. Such observations imply prolonged maternal care which would, as suggested by Kasuya \& March (1984), be directed towards their own progeny. Secondly, pilot whale pods are reported to be very cohesive (Joensen, 1976). This is particularly seen during the drive process, where whales seldom break away from the main group. When a split does occur, the two groups often rejoin. Indeed, there is a Faeroese saying 'the whales return to the blood'. This means that if a group of whales breaks away during the actual killing, when the sea contains blood, they are usually seen to rejoin the 
mêlée instead of heading towards the safety of the open sea. This behaviour might be considered strange if pods contained a random assemblage of animals. Finally, long-term observations made on another Delphinid, the killer whale, Orcinus orca demonstrate a highly stable matrilineal structure with offspring remaining with their mothers for many years (Bigg et al., 1976; Balcomb \& Bigg, 1986).

Each year a total of some 1700-2000 whales are killed and eaten by the Faeroe Islanders. A recent programme of research on these whales has yielded data on sex, age, weight, girth, length, reproductive condition, parasite load, pollutant load, energetics and other biological measurements. Tissue samples were also taken for genetic analysis by DNA fingerprinting (Jeffreys et al., 1985a; Jeffreys et al., 1985b). This technique is now widely used to assess relatedness and, more specifically, paternity in natural populations (Amos et al., 1991; Wetton et al., 1987; Burke et al., 1989; for review see Burke, 1989). In this paper we report the findings of a study in which DNA fingerprinting was used to examine relatedness and parentage within pods.

\section{Methods}

The samples of whales in this investigation were collected from animals slaughtered in the Faeroese drive fishery. Sample sizes were thus determined by the size of each pod. This produced a major statistical problem because sample sizes could not be increased and data from different pods could not be pooled because of heterogeneity between samples (see below). Formal statistical tests were, therefore, only applied where the data conformed to conventional assumptions. In other cases, exact tests were used to illustrate points that we felt were worth reporting. We are aware, however, that the biology of the pilot whale may, in many cases, preclude the application of conventional tests of hypotheses and that the only test of many of our interpretations may depend on the accumulation of further data and the test of consistency of observation.

DNA was extracted from skin or kidney tissue by proteinase $\mathrm{K}$ digestion (in: $100 \mathrm{~mm} \mathrm{NaCl}, 50 \mathrm{~mm}$ Tris $\mathrm{pH}$ 8.0, $20 \mathrm{~mm}$ EDTA, 1 per cent SDS), followed by sequential extractions with phenol then chloroform and a lithium chloride precipitation (aqueous phase adjusted to $2.5 \mathrm{M} \mathrm{LiCl}$, incubation for $30 \mathrm{~min}$ at $-20^{\circ} \mathrm{C}$, centrifugation at $12,000 \mathrm{~g}$ and direct precipitation of DNA from the supernatant with two volumes of ethanol). DNA $(\sim 2 \mu \mathrm{g})$ was digested with $8 \mathrm{u}$ of Dde 1 overnight at $37^{\circ} \mathrm{C}$, ethanol precipitated and electrophoresed through a 0.8 per cent agarose gel in TBE buffer (multilocus fingerprints) or a 0.45 per cent gel in TAE (single locus analysis - see below). DNA was then depurinated with $0.25 \mathrm{M} \mathrm{HCI}$ and vacuum blotted onto Amersham 'Hybond' nylon membrane. Hybridization to single-stranded, primer extended, $\alpha$-32P-labelled 33.15 polycore probe DNA was carried out in $1 \times \mathrm{SSC}, 0.5$ per cent SDS and 4 per cent PEG 6000 overnight. The alternative human polycore probe 33.6 was also tested, but was found to be rather uninformative for two reasons. First, the majority of bands to which it hybridized were also detected by 33.15 and second, 33.6 hybridized strongly to several whale satellite bands. Heparin (50 $\left.\mu \mathrm{g} \mathrm{ml}^{-1}\right)$ and tRNA $\left(5 \mu \mathrm{g} \mathrm{ml}^{-1}\right)$ were used as blocking agents. Filters were exposed for $4 \mathrm{~h}$ to 2 days with an intensifying screen. Multilocus pilot whale fingerprints are shown in Fig. 1a.

In the high molecular weight range (17-50 kb) there is a region in which the only bands present behave as if they are alleles derived from a single locus. In over 350 individuals scored, all either have one strong band or two weaker bands and females always share one band with their offspring. Of 350 individuals 260, drawn from seven pods, were scored by reference to a standard marker comprising a cocktail of four individuals (genotypes; AK, CJ, FG and DH, see Fig. 1b). The putative high molecular weight (HMW) locus is highly polymorphic, with 18 different alleles, none of which predominates. The overall distribution of allele frequencies among these individuals is shown in Fig. 2a. $F$ is the most frequent allele and $F$ the rarest, at frequencies of 25 per cent and 0.2 per cent respectively. Fetuses were not included in the data set.

Multilocus DNA fingerprints were prepared for all of the mother-fetus pairs and mature males taken from five pods in which sampling is thought to have been complete. Pod size ranged from 16 to 103 animals, containing a total of 34 mother-fetus pairs and 37 adult males (as judged by testes weight). Table 1 gives details pod composition; in addition, all individuals in the two largest pods sampled, Miðvágur (24.07.87) and Leynar (22.07.87) were typed for their HMW genotypes.

\section{Results}

\section{DNA fingerprinting}

The degree of variability shown by a fingerprint profile is often quantified in terms of the band-sharing coefficient, i.e. the proportion of bands which are common between two individuals. This value can only act as a rough guide because it is dependent on, amongst other parameters, the sequence of the probe used, the region of the gel over which bands are scored, the resolution 

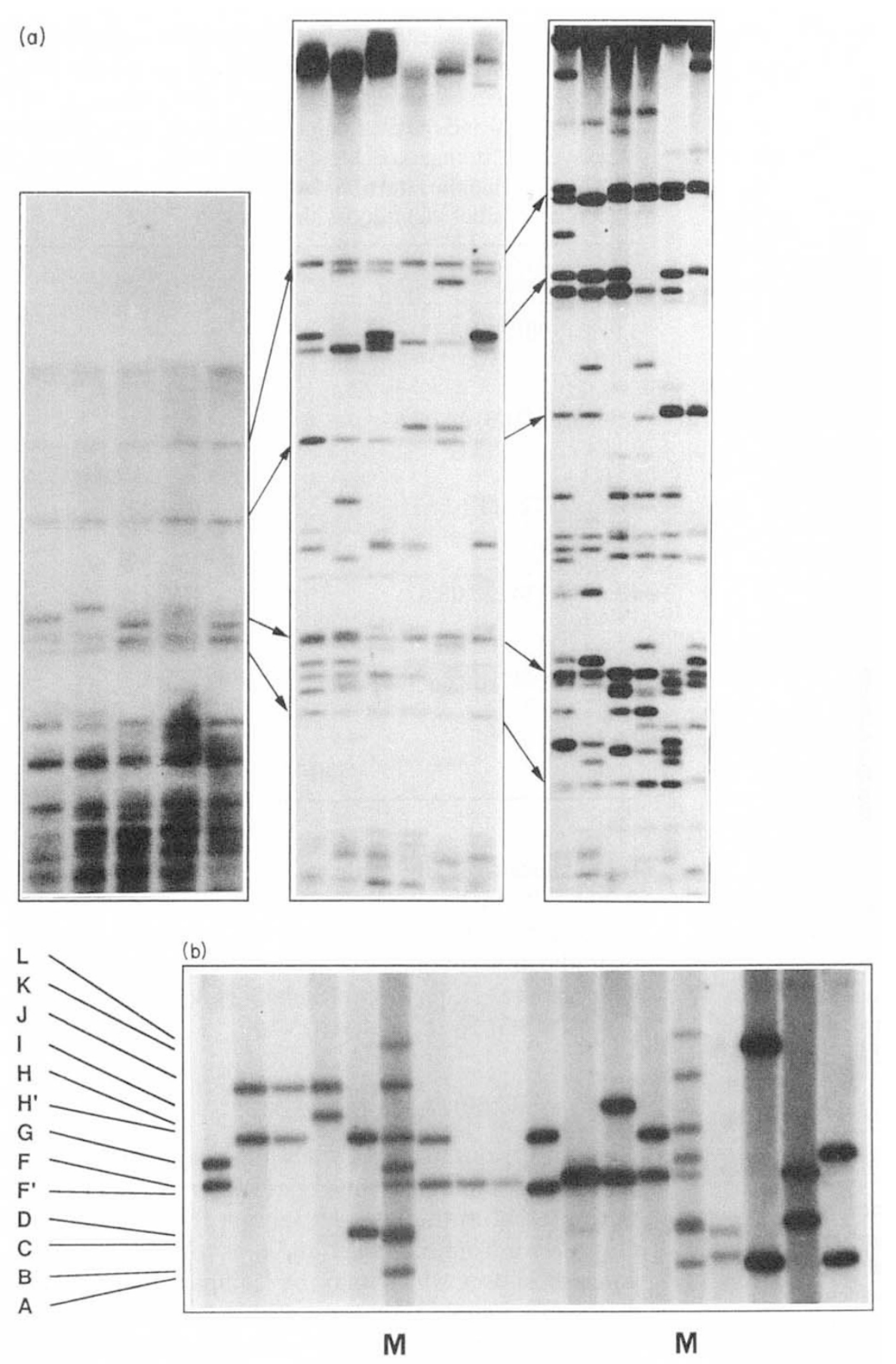

Fig. 1 (a) DNA fingerprints of longfinned pilot whales showing the highly structured profile and increased resolution achieved with optimisation of experimental conditions. (b): Resolution of a single minisatellite locus. Pilot whale genomic DNA was digested with restriction enzyme Dde 1 , electrophoresed through a 0.45 per cent agarose gel and hybridized to the human polycore probe 33.15 . Thirteen alleles are illustrated. Marker lanes are indicated with an ' $\mathrm{M}$ ' and contained alleles A, C, D, F, G, H, J and L. Alleles $\mathrm{C}$ and $\mathrm{D}$ are very close together and appear as one thick band on this gel. Molecular weights range from 20 to $50 \mathrm{~kb}$. of the gel, the hybridization stringency and the restriction enzyme used to cut the DNA. Nevertheless, the band-sharing coefficient does provide a useful indication of variability. Using this measure, pilot whale fingerprints revealed considerably less variability (average band-sharing coefficient for randomly selected individuals from different pods was about 0.56 , range $0.37-0.78$ ) than those of humans and birds [band-sharing coefficients 0.1-0.3 (Jeffreys et al., 1986; Burke \& Bruford, 1987)]. This lower variability leads to reduced confidence limits for positive paternity assignments and individual identity, although powerful paternity exclusion analysis is still possible.

\section{Female relatedness}

All animals from the two largest pods examined [Miðvágur 24.07.87 (103 animals) and Leynar 22.07.87 (90 animals)] were typed for their HMW alleles. Figure $2 b$ illustrates, for female animals only, how allele frequencies differ between these two pods. Although there were considerable differences in the 

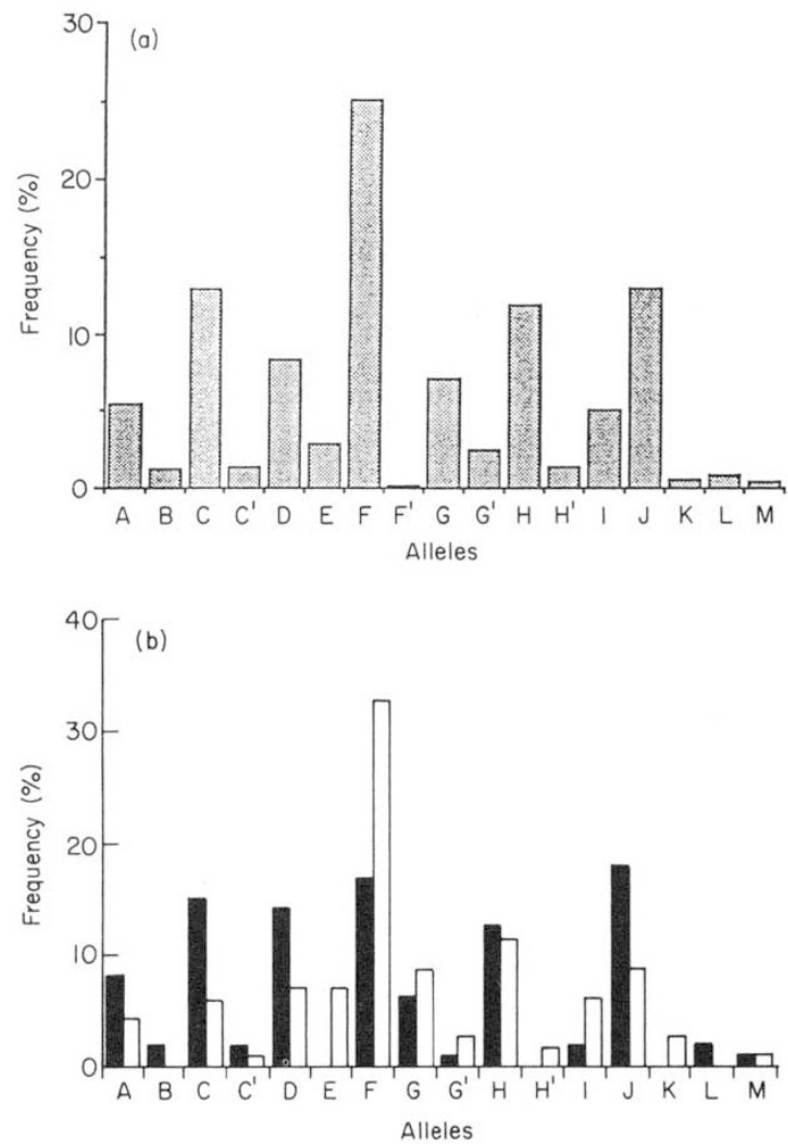

Fig. 2 (a) Overall distribution of alleles observed at the high molecular weight locus. Individuals are drawn from seven pods and include all animals of age/sex classes except fetuses. (b): Comparison of allelic distributions for adult females from two different pilot whale pods, Miðvágur 24.07.87 ( $\square, n=112$ alleles) and Leynar 22.07.87 ( $\square$, $n=106$ alleles).

Table 1 Paternally derived fetal alleles in the larger pods, partitioned by pod and the year of conception. Data from mother-fetus pairs which allow the maternal (and hence paternal) allele to be identified, except $*(J)$ which is from a fetus whose mother was not sampled. In two instances, at Hvalvik, the fetus and its mother were identical. Both fetal alleles are thus indicated

Year of conception

$1986 \quad 1987$

Pod

Paternal alleles in fetuses $\dagger$

\begin{tabular}{lll}
\hline Leynar 22.07.87 & $\mathrm{C} \mathrm{C} \mathrm{G}^{\prime} \mathrm{E}$ & $\mathrm{HHHHJ}(\mathrm{J})^{*}$ \\
Miðvágur 24.07.08 & $\mathrm{J} \mathrm{A} \mathrm{G}^{\prime}$ & $\mathrm{ACCCD} \mathrm{D} \mathrm{D}$ \\
& & $\mathrm{H}^{\prime} \mathrm{H}^{\prime} \mathrm{I} \mathrm{J}$ \\
Hvalvik 24.10.87 & & $\mathrm{HF} \mathrm{H/F} \mathrm{C/F} \mathrm{C}$ \\
\hline
\end{tabular}

Table 2 Exclusion paternity data for five pilot whale pods. The total number of animals is given in brackets for each pod, the number of mother-fetus pairs is indicated by a female symbol and the total number of mature males by the male symbol. Matings are classified into 'excluded' (father not found within the fetal pod) and 'non-excluded' (possible or probable father identifted within fetal pod)

\begin{tabular}{|c|c|c|}
\hline Pod & Excluded & Not excluded \\
\hline \multicolumn{3}{|c|}{ Leynar $(90) 22.07 .87$} \\
\hline $\begin{array}{l}10 \text { ㅇ } \\
110^{\circ}\end{array}$ & 9 & 1 \\
\hline \multicolumn{3}{|c|}{ Miðvágur (103) 24.07.87 } \\
\hline $\begin{array}{l}14 \% \\
80^{\circ}\end{array}$ & 12 & 2 \\
\hline \multicolumn{3}{|c|}{ Hvalvik (72) 24.10 .87} \\
\hline $\begin{array}{l}69 \\
110^{\circ}\end{array}$ & 6 & 0 \\
\hline \multicolumn{3}{|c|}{ Klaksvik (14) 29.08.87 } \\
\hline $\begin{array}{l}3 \% \\
20\end{array}$ & 2 & 1 \\
\hline \multicolumn{3}{|c|}{ Miðvágur (47) 02.08.87 } \\
\hline $\begin{array}{l}1 \% \\
50^{\circ}\end{array}$ & 1 & 0 \\
\hline Total & 30 & 4 \\
\hline
\end{tabular}

frequencies of many of the alleles $\left(\chi^{2}=43.506,9\right.$ d.f., $0.001 \gg P$; allelic classes pooled to provide expected values greater than 5), there are also similarities in the overall pattern of alleles which are common and alleles which are rare (Spearman Rank Correlation, corrected for ties, $\left.r_{\mathrm{s}}=0.76, N=16,0.01 \gg P\right)$.

\section{Paternity within and between pods}

The fingerprint band profiles of each mother-fetus pair were compared to investigate paternity. Bands that were present in the fetus but absent from the mother must derive from the father and thus form a diagnostic paternal subset which may be compared with likely males. By combining the mean number of diagnostic paternal bands $(6.0 \pm 2.17)$ with the average bandsharing coefficient $(0.56)$ it was possible to estimate how many males will appear to be the father by chance alone. It was calculated that on average a fetus will match about one in 32 males by chance. In practice, the power of elimination is greater because paternal bands are not random; they may only be identified where they are absent from the mother. The more frequently a band occurs, the greater the chance that, even if paternal in origin, the mother also has it. The identified subject will, therefore, tend to contain a greater proportion of rarer, more informative bands. Often a single rare band may eliminate all males within a pod. 
Table 3 Likelihoods of obtaining the observed array of fetal alleles in the 1987 Leynar cohort for different combinations of putative paternal genotypes

\begin{tabular}{llll}
\hline $\begin{array}{l}\text { Paternal } \\
\text { genotype(s) }\end{array}$ & $x_{1} \dagger$ & $x_{2} \ddagger$ & $L \S$ \\
\hline JH & $3.08 \times 10^{-2}$ & $1.56 \times 10^{-1}$ & $4.87 \times 10^{-3}$ \\
$\mathrm{HH}, \mathrm{JH}$ & $8.76 \times 10^{-4}$ & $3.96 \times 10^{-1}$ & $3.46 \times 10^{-4}$ \\
$\mathrm{JH}, \mathrm{JH}$ & $9.50 \times 10^{-4}$ & $1.56 \times 10^{-1}$ & $1.48 \times 10^{-4}$ \\
$\mathrm{JH}, \mathrm{JJ}$ & $1.03 \times 10^{-3}$ & $1.46 \times 10^{-2}$ & $1.51 \times 10^{-5}$ \\
$\mathrm{HX}, \mathrm{HX} *$ & $6.96 \times 10^{-2}$ & $4.88 \times 10^{-3}$ & $3.40 \times 10^{-4}$ \\
$\mathrm{JH}, \mathrm{HX}$ & $1.10 \times 10^{-2}$ & $7.81 \times 10^{-2}$ & $8.36 \times 10^{-4}$ \\
$\mathrm{JJ}, \mathrm{HH}$ & $4.75 \times 10^{-4}$ & $1.56 \times 10^{-1}$ & $7.42 \times 10^{-5}$ \\
$\mathrm{JJ}, \mathrm{HX}$ & $5.99 \times 10^{-3}$ & $9.77 \times 10^{-3}$ & $5.85 \times 10^{-5}$ \\
$\mathrm{HH}, \mathrm{JX}$ & $5.52 \times 10^{-3}$ & $7.81 \times 10^{-2}$ & $4.31 \times 10^{-4}$ \\
$\mathrm{HJ}, \mathrm{JX}$ & $1.20 \times 10^{-2}$ & $9.77 \times 10^{-3}$ & $1.17 \times 10^{-4}$ \\
Random $\pi$ & - & - & $1.31 \times 10^{-4}$ \\
\hline
\end{tabular}

$* \mathrm{X}$ denotes all alleles other than $\mathrm{H}$ or $\mathrm{J}$.

$\dagger x_{1}$ is the probability of obtaining the set of paternal genotypes from a population at, or near, Hardy-Weinberg equilibrium (goodness of fit $\chi^{2}=1.05,1$ d.f. ns); the allele frequencies have been obtained by pooling all Faroese samples.

$\ddagger x_{2}$ is the probability of obtaining exactly the observed set of fetuses, given the paternal genotypes

$x_{2}=\frac{5 !}{4 ! 1 ! 0 !} q_{\mathrm{J}} q_{\mathrm{H}} q_{\mathrm{x}}$

where $q_{\mathrm{J}}, q_{\mathrm{H}}, q_{\mathrm{X}}$ are the frequencies of the $\mathrm{J}, \mathrm{H}$ and $\mathrm{X}$ alleles respectively in the paternal genotype(s).

$\S L$ is the likelihood of obtaining the observed array of fetal alleles, i.e.

$L=x_{1} \times x_{2}$

IThis is the likelihood of obtaining the observed set of fetal alleles, if each fetus has been fathered by a different male and is estimated as the probability of drawing four $\mathrm{H}$ alleles and one $\mathrm{J}$ allele at random from the population.
Multilocus paternity exclusion analysis was performed on five pods in which sampling was thought to be complete, comparing each mother-fetus pair with all mature males (about 10 per cent of individuals) from all pods. In all but the most obvious cases, comparisons were made between individuals run on the same gel, and usually in adjacent lanes. During this analysis de novo mutations (those that occurred between parent and fetus) were ignored because, even with the high mutation rates reported for minisatellite loci, the error rate introduced through this assumption was less than 1 per cent. Futhermore, the low levels of minisatellite variability observed in pilot whales suggested a correspondingly low mutation rate.

The paternity exclusion data are summarized in Table 2. It is important to remember that the "notexcluded' figures represent maxima for the possible numbers of fathers because, by the use of further hypervariable probes, it may prove possible to exclude additional males from this category. Two features of pilot whale breeding habits are revealed.

In 88 per cent $(30 / 34)$ of mother-fetus pairs all males from the same pod could be eliminated as fathers. As a total of 299 within-pod paternity tests were conducted, this was equivalent to a non-exclusion rate of 1 in 75 .

The relationship between fetal length and paternity is shown in Fig. 3. The average length of fetuses for which a possible father was located in the fetus' pod, was $8.8 \mathrm{~cm}$, compared with the average length of a fetus where the father was not present at the time of harvesting, which was $56.7 \mathrm{~cm}$. This suggests that inpod matings are associated with small fetuses. Indeed, no in-pod mating was observed for a fetus greater than $20 \mathrm{~cm}$ in length, equivalent to about 5 months in age (A. Martin, personal communication). Although the sample sizes are small, this difference is significant,
Fig. 3 Histogram showing the distribution of fetal lengths analysed, with the data partitioned into whether or not the father was found in the fetal pod. (ㅁ) Mother-fetus pairs where all accompanying males could be excluded. ( $\mathbf{-}$ Instances where all accompanying males could not be excluded.

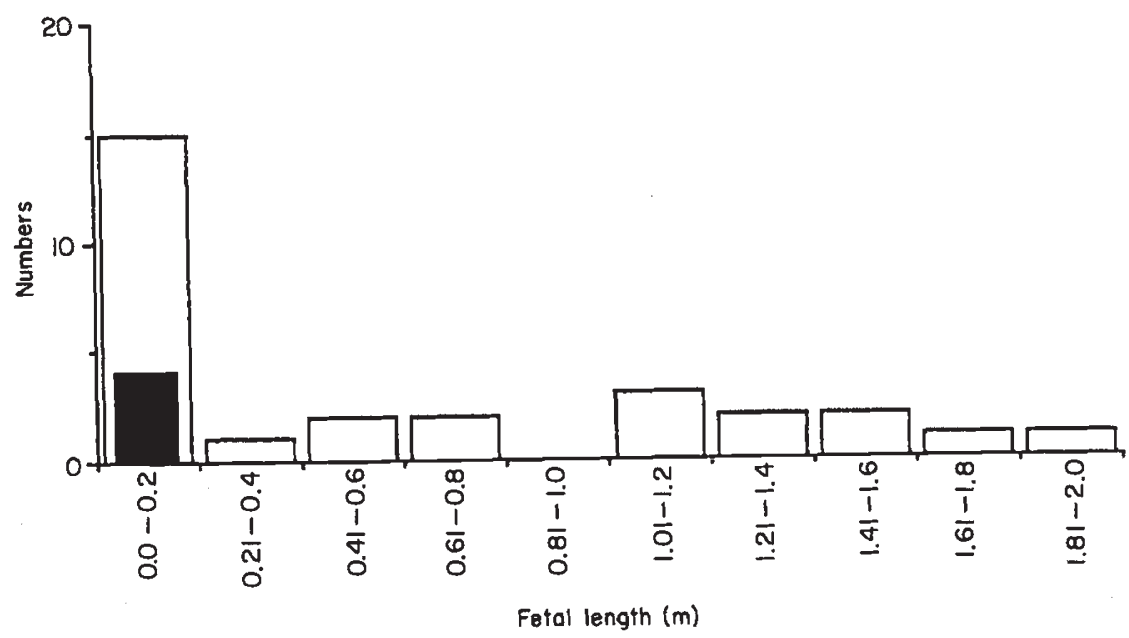


(Mann-Whitney $U$-test, $U=114$, corrected for ties, $t_{\mathrm{s}}=2.02,0.05>P>0.02$ ), which suggests that if males remain with the females with which they have mated, they do so for only a few months. A caveat should be added here that if one further paternity is excluded through the use of other molecular probes, this test becomes non-significant. The possibility that successful males escape during the drive process is unlikely (see below).

When testing for paternity, comparisions were not restricted to within pods. All adult males in the five study pods $(n=37)$ were compared with each single mother-fetus pair $(n=34)$. In only one instance was a potential father found in a non-maternal pod, equivalent to a non-exclusion rate of 1 in 959 . Although such a rate might be expected through chance alone (see above), it is interesting to note that the two pods involved, Miðvágur (24.07.87) and Leynar (22.07.87), were harvested within 2 days of each other. It is therefore possible that the male concerned moved from one pod to the other when the two groups converged at the Faeroe Islands.

\section{Fetal cohort analysis}

Pilot whales have a gestation period of about 15 months and tend to mate in early summer (Sergeant, 1962). Pods harvested in July thus contain two cohorts of fetuses: young ( $<20 \mathrm{~cm}$ in length) and old $(>1 \mathrm{~m}$ in length). In the two largest pods, these lengths correspond to fetuses conceived in 1987 and 1986. Patterns of mating within and between these cohorts were examined through analysis of the HMW alleles.

For a given locus, each fetus received one allele from its mother and one from its father. As both the maternal and the fetal alleles may be determined, the paternal contribution is readily deduced, even in his absence. At highly polymorphic loci this single paternal band can be highly informative. Paternally derived HMW locus alleles were deduced for all fetuses in the three largest pods and are presented in Table 1, classed by pod and by the year of conception.

If we consider only the five fetuses with known paternal alleles from the 1987 Leynar cohort, it is seen that only two alleles are represented, $\mathrm{J}$ and $\mathrm{H}$. The likelihood that a single male, with genotypes $\mathrm{JH}$, fathered these fetuses is 36 times larger than the likelihood that each fetus has a different father (Table 3). If these fetuses were fathered by two males, each of which were carrying at least one $\mathrm{H}$ or $\mathrm{J}$ allele, the likelihood of a single father is still at least five times larger than any specific two-male combination and twice as large as the combined likelihoods of all combinations of two fathers. Whilst the possibility that two or more males fathered the fetuses conceived in 1987 cannot be excluded, the data favour the hypothesis of a single father for this cohort of fetuses. These figures do not take into account the possibility that brothers of halfbrothers might have been involved.

The remaining fetuses, conceived in 1986, have different alleles and require at least two fathers. The hypothetical HJ male which was successful in 1987 could not have been reponsible for any of the 1986 fetuses. A similar difference is noted between fetal age classes at Miðvágur.

Rigorous analysis of the extent of polygyny is difficult, except in an extreme case such as that given above. Nonetheless, it is clear that the allelic distributions amongst the other cohorts are non-random. For example, in Miðvágur 1987, there were two rare $\mathrm{H}$ alleles, 3Cs, 3Ds and, perhaps most significantly, no $\mathrm{F}$ alleles. On its own, the absence of an F allele amongst 11 fetuses would be unlikely under a model in which the paternal alleles are randomly and independently selected from the gene pool, occurring in only 0.04 of cases (assumed frequency $=25$ per cent).

Overall the results from the analysis of paternal alleles are suggestive of individual males fertilizing more than one female, and of the male contribution to cohort changing from year to year. The observation that fathers are seldom, if ever, found in the same pod as their unborn offspring further supports the latter interpretation.

\section{Disussion}

The Faroese pilot whale harvest relies on the strong inshore herding of this species and, indeed, animals which have escaped the initial drive are often observed to rejoin the rest of the pod during the slaughter. Offshore, pilot whales retain a pod structure and it seems reasonable to assume that a similar structure is maintained inshore, rather than the pods being random groups of individuals. The highly significant difference in allele frequencies observed between the two drives at Leynar (22.07.87) and Miðvágur (24.07.87), made in close proximity and only two days apart, suggests that these pods were not random samples taken from an inshore population. If the pod structure is retained for any length of time, then the substantial differences in allele frequencies observed would imply strong population subdivision and inbreeding, resulting in genetic divergence between the pods. Interestingly, although the two pods, Miðvágur (24.07.87) and Leynar (22.07.87) show large differences in allelic frequencies, the ranking of allele frequencies is very similar. This suggests either that the two pods have 
separated very recently or that there is a gene flow between pods.

Evidence concerning the possibility of gene flow between pods comes from the analysis of paternity. Given the observation that drives do, in general, lead to the complete sampling of pods, the observation that fathers of fetuses older than about 5 months are not sampled in a drive suggests that, although pods may be distinct behavioural, genetical or social units, they may not be distinct reproductive units. Hence, the level of inbreeding implied by the size of the pod may not be realized. It might be argued that reproductively active males are able to escape drives. However, we were told by Faroese fishermen that, although they occasionally see one or two large animals break away and escape during the drive process, this is relatively rare. Futhermore, they were confident that such an event would be unlikely to go unnoticed. No escapees were noted for the pods under study. Futher support for the assertion that the results are not being distorted by incomplete sampling comes from the observation that successive cohorts of fetuses have different fathers. This is important because the sampling of different fetal cohorts is independent of the harvesting process.

As the comparison of allele frequencies made between Miðvágur and Leynar included only females, the genetic differentiation observed suggests that the structure of the pod is basically matrilineal, i.e. that related females tend to stay together. The behaviour of males is, however, more equivocal. On the basis of the data presented here, it is not impossible that males remain with their natal pods but are behaviourally inhibited from mating with accompanying, and hence presumably related, females. In this case, males would mate with females from other pods when they were encountered, possibly in the large aggregation of whales noted out at sea. The alternative behaviour is for males to move regularly between pods, possibly in groups, staying only for a short period of time and mating with females as they come into oestrus. To discriminate between these two alternatives would require a longitudinal study of inividual pods, but sampling from the Faroese drives precludes this approach.

\section{Acknowledgements}

We thank the Natural Research Council (GB); The Sea Mammal Research Unit (Cambridge) and the International Whaling Commission for support. We which to thank the Faeroese government for providing facilities to sample the whales and to all who participated in the sampling. We would like to express special gratitude to Rogvi Mouritsen, Dorete Bloch and
Genevieve Desportes, for their hard work in the yearround sampling operation, and to John Brookfield for his generous help and discussion on the problem of estimating the number of fathers. Tamsin Majerus provided technical assistance. Many helpful comments were contributed by Josephine Pemberton, Nick Davies and Steve Albon.

\section{References}

AMOS, W., BARRETT, J. A. AND DOVER, G. A. 1991. Breeding system and social structure in the Faeroese pilot whale as revealed by DNA fingerprinting. Rep. Int. Whal. Commn. (Special Issue) (In Press).

BALCOMB, K. C. AND BIGG, M. A. 1986. Population biology of three resident killer whale pods in Puget Sound and off Southern Vancouver Island. In: Kirkevold, B. and Lockard, J. S. (eds) Behavioural Biology of Killer Wales. Alan R. Liss, inc., New York. pp. 85-95.

BIGG, M. A., MACASKIE, I. B. AND ELLIS, G. 1976. Abundance and movements of killer whales off eastern and southern Vancouver Island with comments on management. In: Preliminary Report Arctic Biol. Sta. Ste. Anne de Bellevue, Quebec, Canada.

BURKE, T. 1989. DNA fingerprinting and other methods for the study of mating success. Trends Ecol. Evol. 4, $139-144$.

BURKE, T. AND BRUFORD, M. W., 1987. DNA fingerprinting in birds. Nature, 327, 149-152.

BURKE, T., DAVIES, N. B., BRUFORD, M. W. AND HATCHWELL, B. J. 1989. Parental care and mating behaviour of polyandrous dunnocks Prunella modularis related to paternity by DNA fingerprinting. Nature, 338, 249-251.

JEFFREYS, A. J., BROOKFIELD, J. F. Y. AND SEMEONOFF, R. 1985. POSitive identification of an immigration test-case using human DNA fingerprints. Nature, 317, 818-819.

JEFFREYS, A. J., WILSON, V. AND THEIN, S. L. 1985a. Hypervariable 'minisatellite' regions in human DNA. Nature, 316, 67-73.

JEFFREYS, A. J., WILSON V. AND THEIN, S.L. 1985b. Individualspecific 'fingerprints' of human DNA. Nature, 316, 76-79. JOENSEN, J. P. 1976. Pilot Whaling in the Faroe Islands. Reprinted from: Ethnol. Scand. Berlingska Boktryckeriet Lund.

KASUYA, T. AND MARCH, H. 1984. Life history and reproductive biology of the short-finned pilot whale, Globicephala macrorhynchus, off the Pacific coast of Japan. Rep. Int. Whal. Commn. (Special Issue 6) 259-310.

NICLASSEN, P. 1945. Foeroerne i kronikker og foredrag. Kobenhaven. (cited by Joensen.)

A RYGGl, M. D. 1953. Dyralaera 1, Sugdyr. Torshavn. (cited by Joensen.)

SERGEANT, D.E. 1962. The biology of the pilot whale or pothead whale Globicephala melas (Traill) in Newfoundland waters. Bull. Fish. Res. Board Can. 132, $1-84$.

WETTON, J. H., CARTER, R. E., PARKIN, D. T. AND WALTERS, D., 1987. Demographic study of a wild house sparrow population by DNA fingerprinting. Nature, 327, 147-149. 